\title{
Ethylene Evolution is Positively Correlated with Seed Vigor in Sweet Corn and Tomato Seed Lots with Differing Vigor Levels but Similar Germination Capacity
}

\author{
Gunching Siriwitayawan, A. Bruce Downie, and Robert L.Geneve ${ }^{1}$ \\ Department of Horticulture, University of Kentucky, Lexington, KY 40546
}

AdDitional INDEX words. Zea mays, Lycopersicon esculentum, seed deterioration, seed aging, vigor, ACC oxidase

\begin{abstract}
Sweet corn (Zea mays L.) and tomato (Lycopersicon esculentum Mill.) seeds were aged naturally for 18 months or artificially aged using saturated salt accelerated aging to provide seed lots that differed in seed vigor, but retained a high standard germination percentage. Seed vigor was confirmed using standard vigor tests, including time to radicle emergence, cold, and accelerated aging tests. Ethylene evolution from both sweet corn and tomato seeds during germination was positively correlated with seed quality. Differences in ethylene evolution between nonaged and aged seeds were greater in seeds germinated on exogenous 1-aminocyclopropane-1-carboxylic acid (ACC). After 36 hours, there was about a 15-fold increase in ethylene evolution from seeds treated with 5 mM ACC compared to untreated seeds. Naturally and artificially aged seeds responded similarly and showed reduced ethylene production compared to nonaged seeds. In contrast to ethylene production, endogenous ACC titers were less for nonaged compared to aged seeds. Exogenous application of ACC to artificially aged seeds reduced the time to radicle protrusion, but did not completely reverse age-related effects on vigor. The data indicate that the reduced ability to produce ethylene in aged seeds was related to ACC oxidase (ACCO) synthesis or activity. Using Northern blot analysis, $A C C O$ mRNA was detected after 48 hours of imbibition in nonaged seeds, but was undetectable in aged seeds affirming the contention that ACCO synthesis was delayed or reduced by aging. The current study provides additional support for ethylene as a biochemical indicator of seed vigor in seed lots with reduced vigor but high germination capacity.
\end{abstract}

Standard germination tests are conducted under optimal environmental conditions and provide an appropriate estimate of seed viability, but in most cases, do not provide an adequate prediction of seedling emergence under field conditions (TeKrony and Egli, 1991; van de Venter et al., 1993). Therefore, seed vigor tests were developed as better determinants of a seed's capacity for seedling establishment under less than ideal conditions (Byrum and Copeland, 1995). Seed vigor is defined as the ability of seeds to complete germination successfully and establish normal seedlings under a wide range of field conditions [Association of Official Seed Analysts (AOSA), 1983]. Seed vigor tests can be categorized into physiological or biochemical tests. Physiological tests measure some aspect of germination and seedling growth, while biochemical tests evaluate a specific chemical reaction or reactions associated with germination (Woodstock, 1973).

Physiological vigor tests often impose a stress on seeds during germination followed by determination of normal seedling development (Copeland and McDonald, 1995). The most common physiological vigor tests are cold, controlled deterioration, and accelerated aging tests. Physiological vigor tests that do not usually contain a stress period measure seedling growth or some aspect of germination rate. Although physiological vigor tests are the most widely used tests by commercial and public seed testing labs, they are time consuming to conduct ( $>10 \mathrm{~d}$ in some cases) and require strict environmental control for consistent results between labs (Byrum and Copeland, 1995; McDonald, 1995).

Biochemical tests for vigor assessment provide a rapid determination of biochemical changes following imbibition and are usually completed before radicle emergence (Copeland and McDonald, 1995). These include tetrazolium, conductivity, adenosine

Received for publication 16 Oct. 2002. Accepted for publication 18 Mar. 2003 University of Kentucky Experiment Station publication \#02-11-170.

'Rgeneve@uky.edu. triphosphate (ATP), and glutamic acid decarboxylase activity (GADA) tests. Biochemical tests for vigor are not routinely used by seed technology labs because of the complexity of the tests and an inconsistent correlation with seedling emergence.

Ethylene is an easily measured volatile compound and appears to be ubiquitously produced in nondormant seeds following imbibition with a sharp increase associated with radicle emergence (Matilla, 2000). The ability to evolve ethylene has been suggested as a seed vigor test (Khan, 1994). Numerous studies have shown a positive correlation between seed quality in diverse species and ethylene production (Gorecki et al., 1991; Ketring et al., 1974; Khan, 1994; Takayanagi and Harrington, 1971). These studies used natural or artificial seed aging to obtain deteriorated seed lots. In all cases, ethylene production was positively correlated with germination capacity. However, these studies evaluated seed lots with seed viability well below those acceptable for use by commercial seed companies. It is difficult to determine from these studies whether ethylene evolution was strictly associated with seed vigor or the seed's capacity to germinate. Therefore, the objective of this study was to determine if ethylene evolution was correlated with seed vigor in lots that differed in vigor as determined by standard physiological vigor tests, but retained similar standard germination percentages.

\section{Materials and Methods}

Seeds from tomato (Lycopersicon esculentum Mill. 'New Yorker', 'Rutgers', and 'Ailsa Craig') and sweet corn (Zea mays L. 'Silver King') were placed in plastic bags and stored at 4 or 23 ${ }^{\circ} \mathrm{C}$. Standard germination followed Association of Official Seed Analysts (1993) rules. Four replications of 50 seeds of sweet corn or tomato seeds were germinated on moist rolled paper towels or blotters in Petri dishes (Anchor, Ohio), respectively. Germination 
was under alternating cycles of $16 \mathrm{~h}$ at $20^{\circ} \mathrm{C}$ for sweet corn or 25 ${ }^{\circ} \mathrm{C}$ for tomato in darkness followed by $8 \mathrm{~h}$ at $30^{\circ} \mathrm{C}$ in light $(20$ $\left.\mu \mathrm{mol} \cdot \mathrm{s}^{-1} \cdot \mathrm{m}^{-2}\right)$. Sweet corn germination counts for vigor were at $3 \mathrm{~d}$ (radicle longer than $1.25 \mathrm{~mm}$ ) and standard germination that included normal and abnormal seedlings at $7 \mathrm{~d}$ (AOSA, 1993). Tomato seed vigor was estimated after $4 \mathrm{~d}$ (radicle longer than 2 $\mathrm{mm}$ ) and standard germination was evaluated after $14 \mathrm{~d}$. The time required for seeds to attain $50 \%$ radicle protrusion was determined from a linear regression of probit transformed germination percent over time. Four replications of 50 seeds were used to estimate speed of germination.

To obtain differences in seed vigor, seeds from a single seed lot of sweet corn or tomato were aged naturally at $23{ }^{\circ} \mathrm{C}$ for 18 months or artificially aged using saturated salt accelerated aging (McDonald, 1998). For artificial aging, 600 seeds of sweet corn or tomato were placed on wire mesh screens over $40 \mathrm{~mL}$ of saturated $\mathrm{KCl}(\approx 78 \%$ relative humidity) in plastic accelerated aging boxes (Hoffman Manufacturing Inc., Ore.) at $45^{\circ} \mathrm{C}$ (McDonald, 1998). Seeds were aged for 3 to $8 \mathrm{~d}$ followed by rapid forced air drying to a fresh weight moisture content near $10 \%$. Aged seeds were evaluated for germination within $24 \mathrm{~h}$ of drying or frozen in liquid nitrogen and stored at $-80{ }^{\circ} \mathrm{C}$ for tissue extraction.

Seed vigor tests for sweet corn and tomato included radicle emergence at 3 or $4 \mathrm{~d}$ as previously described, and the cold and accelerated aging tests (AOSA, 1983). For the saturated tray cold test (modified from TeKrony and Woltz, 1997), two replications of 50 seeds were planted on water-saturated soil (Lanton silty clay loam) obtained from the University of Kentucky Spindletop Research Farm. Before use, soil was sieved through a 20-mesh screen. Subsequently, seeds were planted on the soil surface (for sweet corn, the embryo was in contact with soil) and incubated at $10{ }^{\circ} \mathrm{C}$ for $7 \mathrm{~d}$ in the dark, followed $14 \mathrm{~d}$ at $25^{\circ} \mathrm{C}$ in the dark before being evaluated for normal or abnormal seedlings.

The accelerated aging test used four replications of 100 seeds placed on a wire mesh screen over $20 \mathrm{~mL}$ of distilled water in accelerated aging boxes held at $45^{\circ} \mathrm{C}$ in a water-jacketed chamber for $4 \mathrm{~d}$. Subsequently, seeds were placed under standard germination conditions as previously described and normal germination recorded after 7 (sweet corn) or $14 \mathrm{~d}$ (tomato).

Seed moisture content was determined using the hot air oven method (International Seed Testing Association, 1993). Seed dry weight was measured in four replications of 20 sweet corn or 50 tomato seeds after $3 \mathrm{~d}$ in a $105{ }^{\circ} \mathrm{C}$ drying oven.

Ethylene evolution was measured from seeds treated with or without 1-aminocyclopropane-1-carboxylic acid (ACC). Sweet corn or tomato seeds with differing vigor levels were placed in petri dishes containing ACC ( 0 or $5 \mathrm{~mm}$ ) and held for 12 to $48 \mathrm{~h}$ under germination conditions described above. Ethylene evolution was quantified by moving 15 sweet corn or 50 tomato seeds from the pool of ACC-treated seeds to four replicate, dry 25-mL Erlenmeyer flasks. Flasks were sealed with serum stoppers and a 1-mL gas sample withdrawn after $3 \mathrm{~h}$ of incubation. A Buck Scientific gas chromatograph with flame ionization detector (155 $\left.{ }^{\circ} \mathrm{C}\right)$ and alumina column $\left(125^{\circ} \mathrm{C}\right)$ with a nitrogen flow rate of 1 $\mathrm{mL} / \mathrm{min}$ was used to determine ethylene concentration.

Endogenous ACC was also determined from four replications of 15 sweet corn or 50 tomato seeds (McKeon et al., 1982). Seeds were frozen in liquid nitrogen and stored at $-80^{\circ} \mathrm{C}$ until extracted. Seeds were ground in 5 and $2 \mathrm{~mL}$ of $80 \%$ ethanol for sweet corn or tomato seeds, respectively and incubated at $70{ }^{\circ} \mathrm{C}$ for $30 \mathrm{~min}$. Subsequently, the extract was centrifuged and the aqueous phase transferred into a new tube. The pellet was re-suspended in 1 or
$2.5 \mathrm{~mL}$ of $80 \%$ ethanol and reextracted. The combined extracts were evaporated in vacuo to dryness using an Evapomix at 45 ${ }^{\circ} \mathrm{C}$. Chloroform $(1 \mathrm{~mL})$ plus water $(1 \mathrm{~mL})$ was used to re-suspend and separate recovered ACC into the aqueous phase. ACC quantification was performed as described by Lizada and Yang (1979). The reaction mixture consisted of $0.5 \mathrm{~mL}$ extract plus 0.1 $\mathrm{mL}$ of $0.05 \mathrm{M} \mathrm{HgCl}_{2}$ to which the addition of $0.2 \mathrm{~mL}$ of a $2: 1(\mathrm{v} / \mathrm{v}$ ratio of $5 \% \mathrm{NaOCl}$ and saturated $\mathrm{NaOH}$ initiated the reaction to liberate ethylene. Test tubes were capped with serum stoppers, vortexed for $20 \mathrm{~s}$, and kept on ice. After agitation for $5 \mathrm{~min}$, a 1 -mL gas sample was withdrawn for ethylene measurement as previously described. An internal standard of ACC showed an extraction efficiency of $88 \% \pm 1.9 \%$.

Partial length ACC oxidase ( $A C C O$ ) cDNAs were cloned from reverse transcribed tomato and maize total RNA extracted from seeds. The degenerate primers used to amplify the tomato cDNA were generously provided by A. Inaba and Y. Kubo (Okayama University, Okayama, Japan). The degenerate primers used to amplify the maize cDNA were designed using conserved regions between a sorghum (Sorghum bicolor L., Accession AF079588) and a rice (Oryza sativa L.; Accession AF049889) ACCO cDNA. The 3' end of the maize sequence was obtained by PCR in a 3' RACE with two gene specific nested primers and a poly-T anchor primer with a nonhomologous 5' extension and a primer complementary to it. The partial-length $A C C O$ cDNA from tomato was $\mathrm{LeACCO} 4$ from ripening tomato fruit (Nakatsuka et al., 1998). The maize partial length ACCO cDNA (Accession AY155581) showed $71 \%$ identity at the nucleotide level with a full length cDNA clone from Sorghum (Accession AF079588; Finlayson et al., 1999). The maize clone was $92 \%$ identical, $97 \%$ similar at the amino acid level with the sorghum deduced amino acid sequence.

Sweet corn or tomato seeds $(3 \mathrm{~g})$ treated with or without $5 \mathrm{~mm}$ ACC were pulverized in liquid nitrogen in a prefrozen mortar for RNA extraction. The hot borate method for sweet corn (Wan and Wilkins, 1994) and a modified phenol chloroform extraction method for tomato (Ausubel et al., 1987) were used to isolate total RNA. Total RNA concentration and purity was determined spectrophotometrically at 280, 260, and $230 \mathrm{~nm}$. Subsequently, RNA integrity was examined by formaldehyde gel electrophoresis.

Ten micrograms of RNA was size separated using $1.3 \%$ agarose, denaturing gel electrophoresis and subsequently, transferred overnight onto Hybond $\mathrm{N}^{+}$membrane (Amersham Life Science, Piscataway, N.J.) by capillary transfer. The RNA was cross-linked onto the membrane using a UV light crosslinker at $50 \mathrm{mV} / \mathrm{cm}^{2}$ (BioRad Laboratories, Hercules, Calif.). The partial tomato ACCO cDNA was sub-cloned from pCR2.1 into pBSIIK +/- (Invitrogen Corp., Carlsbad, Calif.) to make a template for in vitro transcription. One microgram of the circular plasmid DNA was exhaustively digested with five units of EcoR V. Radio-labeled, antisense RNA probes were generated from run-off transcription reactions using T3 RNA polymerase and ${ }^{32}$ PUTP(NewEngland Nuclear, Boston, Mass.) and used as a probe in Northern blot analysis of both sweet corn and tomato seed imbibition time courses.

Prehybidization and hybidization were at 68 and $65{ }^{\circ} \mathrm{C}$, respectively in ULTRAhyb hybridization buffers (Ambion, Inc., Austin, Texas). Blots were first washed twice at low stringency in $2 \times$ sodium chloride sodium citrate buffer (SSC) with $0.1 \%$ sodium dodecyl sulfate (SDS) at room temperature and then re-washed twice at high stringency $(0.2 \times \mathrm{SSC}, 0.1 \% \mathrm{SDS}$ at $\left.65{ }^{\circ} \mathrm{C}\right)$. Membranes were briefly rinsed in $2 \times \mathrm{SSC}$, placed on Whatman 3MM paper to remove excess liquid and, while still 
damp, sealed in $69 \mu \mathrm{m}$ plastic bags. Membranes were placed on a preblanked phosphor-screen for 5 to $10 \mathrm{~d}$ depending on signal intensity followed by detection of the hybridized probe using a phosphorimager (Molecular Dynamics, Sunnyvale, California)

Average percentage germination, time to completion of $50 \%$ germination, ACC and ethylene contents were all subjected to analysis of variance to determine if ACC treatments, vigor levels, or their interaction accounted for significant differences. If either of the main effects or their interaction were significant Tukey's mean separation test was performed. If the interaction of the main effects was significant Tukey's test was run on one main effect for each level of the other main effect.

\section{Results}

To obtain differences in seed vigor within the same seed lot, sweet corn and tomato seeds were subjected to natural or saturated salt accelerated aging (SSAA) (Tables 1-3). Using several standard vigor tests as indicators, it was possible to identify aging treatments that resulted in reduced seed vigor, but still retained a high standard germination percentage of normal seedlings. Under natural storage conditions, sweet corn and tomato seed vigor began to deteriorate after one year but the seeds still retained relatively high germination percentage after 18 months (Table 1). For artificially aged seeds, 3 and $5 \mathrm{~d}$ of SSAA for sweet corn (Table 2) and 3 and $4 \mathrm{~d}$ for tomato (Table 3 ) were selected for medium-vigor, and low-vigor seeds, respectively. Standard germination percentages for sweet corn and tomato seeds exposed to these aging treatments were above 86 and $82 \%$ for sweet corn and tomato, respectively. The reduction in standard germination percentage compared to nonaged seeds was from an increase in the number of abnormal seedlings in low-vigor lots of corn and tomato rather than nonliving seeds (data not shown).

High-vigor, nonaged sweet corn and tomato seeds began to evolve detectable amounts of ethylene $\approx 12 \mathrm{~h}$ after being placed on water or exogenous $\mathrm{ACC}$, at least $24 \mathrm{~h}$ before radicle emergence (Figs. 1 and 2). In most cases, high-vigor (nonaged) seeds evolved more ethylene than medium-vigor and low-vigor aged seeds and

Table 1. Sweet corn and tomato ('New Yorker') seed quality after storage at $23{ }^{\circ} \mathrm{C}$ for 18 months.

\begin{tabular}{|c|c|c|c|c|c|c|c|}
\hline \multirow[b]{2}{*}{ Species } & \multirow[b]{2}{*}{$\begin{array}{l}\text { Storage } \\
\text { time } \\
(\mathrm{mo})\end{array}$} & \multirow[b]{2}{*}{$\begin{array}{c}\text { Moisture } \\
(\%)\end{array}$} & \multirow[b]{2}{*}{$\begin{array}{c}\text { Standard } \\
\text { germination } \\
(\%)\end{array}$} & \multicolumn{4}{|c|}{ Vigor assessment (\%) } \\
\hline & & & & $\begin{array}{l}\text { Radicle } \\
\text { protrusion } \\
\text { after } 3 \mathrm{~d}\end{array}$ & $\begin{array}{c}\text { Cold } \\
\text { test }\end{array}$ & $\begin{array}{c}\text { Accelerated } \\
\text { aging } \\
4 \mathrm{~d}\end{array}$ & $\begin{array}{l}\text { Saturated } \\
\text { accelerated } \\
\text { aging } \\
4 \mathrm{~d}\end{array}$ \\
\hline \multirow[t]{3}{*}{ Sweet corn } & 0 & $9.0 \pm 0.1 \mathrm{c}^{\mathrm{z}}$ & $96 \pm 1 \mathrm{a}$ & $92 \pm 2 \mathrm{a}$ & $85 \pm 3 a$ & $46 \pm 3 a$ & $95 \pm 1 \mathrm{a}$ \\
\hline & 12 & $9.7 \pm 0.3 b$ & $92 \pm 2 a b$ & $90 \pm 2 \mathrm{a}$ & $83 \pm 3 \mathrm{a}$ & $43 \pm 2 a b$ & $85 \pm 2 b$ \\
\hline & 18 & $11.0 \pm 0.2 \mathrm{a}$ & $87 \pm 2 b$ & $82 \pm 1 b$ & $67 \pm 4 \mathrm{a}$ & $35 \pm 2 b$ & $63 \pm 2 c$ \\
\hline \multirow[t]{3}{*}{ Tomato } & 0 & $7.5 \pm 0.4 \mathrm{c}$ & $87 \pm 2 \mathrm{a}$ & $63 \pm 3 a$ & $51 \pm 5 a$ & $35 \pm 2 \mathrm{a}$ & $87 \pm 2 a$ \\
\hline & 12 & $8.4 \pm 0.4 b$ & $86 \pm 3 a$ & $62 \pm 4 a$ & $50 \pm 1 \mathrm{a}$ & $32 \pm 1 \mathrm{a}$ & $84 \pm 1 b$ \\
\hline & 18 & $9.5 \pm 0.7 \mathrm{a}$ & $76 \pm 3 b$ & $43 \pm 3 b$ & $41 \pm 3 \mathrm{a}$ & $24 \pm 2 b$ & $58 \pm 2 c$ \\
\hline
\end{tabular}

${ }^{2}$ Means ( \pm standard error) followed by the same letter in a column are not significantly different by LSD $(P \leq 0.05)$.

Table 2. Sweet corn seed quality after exposure to saturated salt accelerated aging (SSAA).

\begin{tabular}{|c|c|c|c|c|c|}
\hline \multirow[b]{2}{*}{$\begin{array}{l}\text { SSAA } \\
\text { (d) }\end{array}$} & \multirow[b]{2}{*}{$\begin{array}{c}\text { Moisture } \\
(\%)\end{array}$} & \multirow[b]{2}{*}{$\begin{array}{c}\text { Standard } \\
\text { germination } \\
(\%)\end{array}$} & \multicolumn{3}{|c|}{ Vigor assessment (\%) } \\
\hline & & & $\begin{array}{c}\text { Radicle } \\
\text { protrusion } \\
\text { after } 3 \mathrm{~d} \\
\end{array}$ & $\begin{array}{c}\text { Cold } \\
\text { test }\end{array}$ & $\begin{array}{c}\text { Accelerated } \\
\text { aging } 4 \mathrm{~d}\end{array}$ \\
\hline 0 & $9.0 \pm 0.1 \mathrm{~d}^{\mathrm{z}}$ & $96 \pm 1 \mathrm{a}$ & $92 \pm 2 \mathrm{a}$ & $85 \pm 3 a$ & $43 \pm 3 \mathrm{a}$ \\
\hline 3 & $13.9 \pm 0.4 \mathrm{c}$ & $92 \pm 1 \mathrm{ab}$ & $86 \pm 2 a$ & $82 \pm 1 \mathrm{a}$ & $32 \pm 3 b$ \\
\hline 4 & $14.5 \pm 0.4 b c$ & $90 \pm 1 \mathrm{ab}$ & $66 \pm 5 b$ & $78 \pm 2 \mathrm{a}$ & $29 \pm 1 b$ \\
\hline 5 & $15.6 \pm 0.4 \mathrm{ab}$ & $86 \pm 3 b$ & $40 \pm 4 c$ & $66 \pm 6 b$ & $28 \pm 3 b$ \\
\hline 6 & $15.6 \pm 0.6 \mathrm{ab}$ & $77 \pm 3 c$ & $35 \pm 4 c$ & $53 \pm 5 b c$ & $26 \pm 2 b$ \\
\hline 7 & $16.0 \pm 0.6 \mathrm{a}$ & $64 \pm 4 d$ & $33 \pm 2 c$ & $45 \pm 9 c$ & $24 \pm 3 b$ \\
\hline 8 & $16.2 \pm 0.1 \mathrm{a}$ & $44 \pm 4 \mathrm{e}$ & $9 \pm 2 d$ & $37 \pm 7 c$ & $14 \pm 3 c$ \\
\hline
\end{tabular}

zMeans ( \pm standard error) followed by the same letter in a column were not significantly different by LSD $(P \leq 0.05)$.

Table 3. Tomato ('NewYorker') seed quality after exposure to saturated salt accelerated aging (SSAA).

\begin{tabular}{|c|c|c|c|c|c|}
\hline \multirow[b]{2}{*}{$\begin{array}{l}\text { SSAA } \\
\text { (d) }\end{array}$} & \multirow[b]{2}{*}{$\begin{array}{c}\text { Moisture } \\
(\%)\end{array}$} & \multirow[b]{2}{*}{$\begin{array}{c}\text { Standard } \\
\text { germination } \\
(\%)\end{array}$} & \multicolumn{3}{|c|}{ Vigor assessment (\%) } \\
\hline & & & $\begin{array}{l}\text { Radicle } \\
\text { protrusion } \\
\text { after } 3 \mathrm{~d}\end{array}$ & $\begin{array}{c}\text { Cold } \\
\text { test }\end{array}$ & $\begin{array}{c}\text { Accelerated } \\
\text { aging } 4 \mathrm{~d}\end{array}$ \\
\hline 0 & $7.5 \pm 0.4 \mathrm{e}^{\mathrm{z}}$ & $87 \pm 2 a$ & $84 \pm 2 \mathrm{a}$ & $51 \pm 5 a$ & $35 \pm 2 a$ \\
\hline 3 & $9.7 \pm 0.6 \mathrm{~d}$ & $84 \pm 2 a$ & $65 \pm 2 b$ & $39 \pm 3 b$ & $25 \pm 1 b$ \\
\hline 4 & $10.4 \pm 0.6 \mathrm{~cd}$ & $82 \pm 1 \mathrm{a}$ & $43 \pm 3 c$ & $28 \pm 1 c$ & $22 \pm 2 b c$ \\
\hline 5 & $11.1 \pm 0.5 \mathrm{~cd}$ & $58 \pm 2 b$ & $36 \pm 2 d$ & $22 \pm 3 \mathrm{~cd}$ & $19 \pm 3 b c$ \\
\hline 6 & $11.8 \pm 0.8 \mathrm{bc}$ & $49 \pm 3 c$ & $22 \pm 5 \mathrm{de}$ & $18 \pm 2 \mathrm{~d}$ & $16 \pm 2 \mathrm{~cd}$ \\
\hline 7 & $12.9 \pm 0.5 b$ & $43 \pm 3 c$ & $16 \pm 4 \mathrm{e}$ & $7 \pm 1 \mathrm{e}$ & $12 \pm 3 \mathrm{de}$ \\
\hline 8 & $14.6 \pm 0.5 \mathrm{a}$ & $44 \pm 5 c$ & $11 \pm 3 \mathrm{e}$ & $2 \pm 2 \mathrm{e}$ & $9 \pm 2 \mathrm{e}$ \\
\hline
\end{tabular}

${ }^{2}$ Means ( \pm standard error) followed by the same letter in a column were not significantly different by LSD $(P \leq 0.05)$. 
Sweet corn

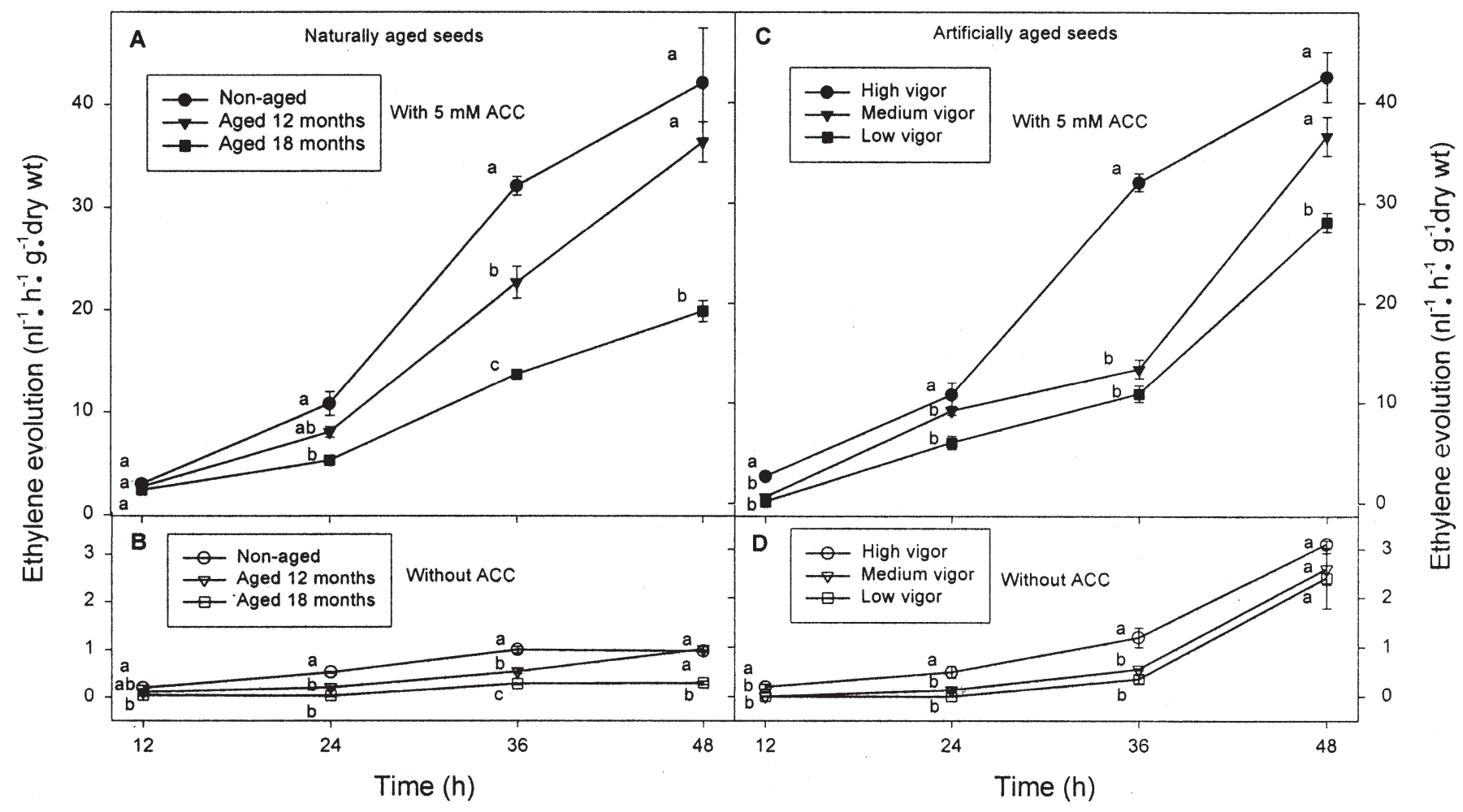

Fig. 1. Ethylene evolution from nonaged, naturally or artificially aged sweet corn seeds treated with or without 5 mm ACC. Values at each evaluation time were separated between aging treatment by Tukey's test $(P \leq 0.05)$. High-vigor seeds commenced radicle protrusion at $36 \mathrm{~h}$ on ACC and at $48 \mathrm{~h}$ on water. Mediumvigor, nonaged, and 12-month naturally aged seeds commenced radicle protrusion at $48 \mathrm{~h}$ and low-vigor/18 month naturally aged seeds at $60 \mathrm{~h}$ regardless of imbibition medium.

Tomato

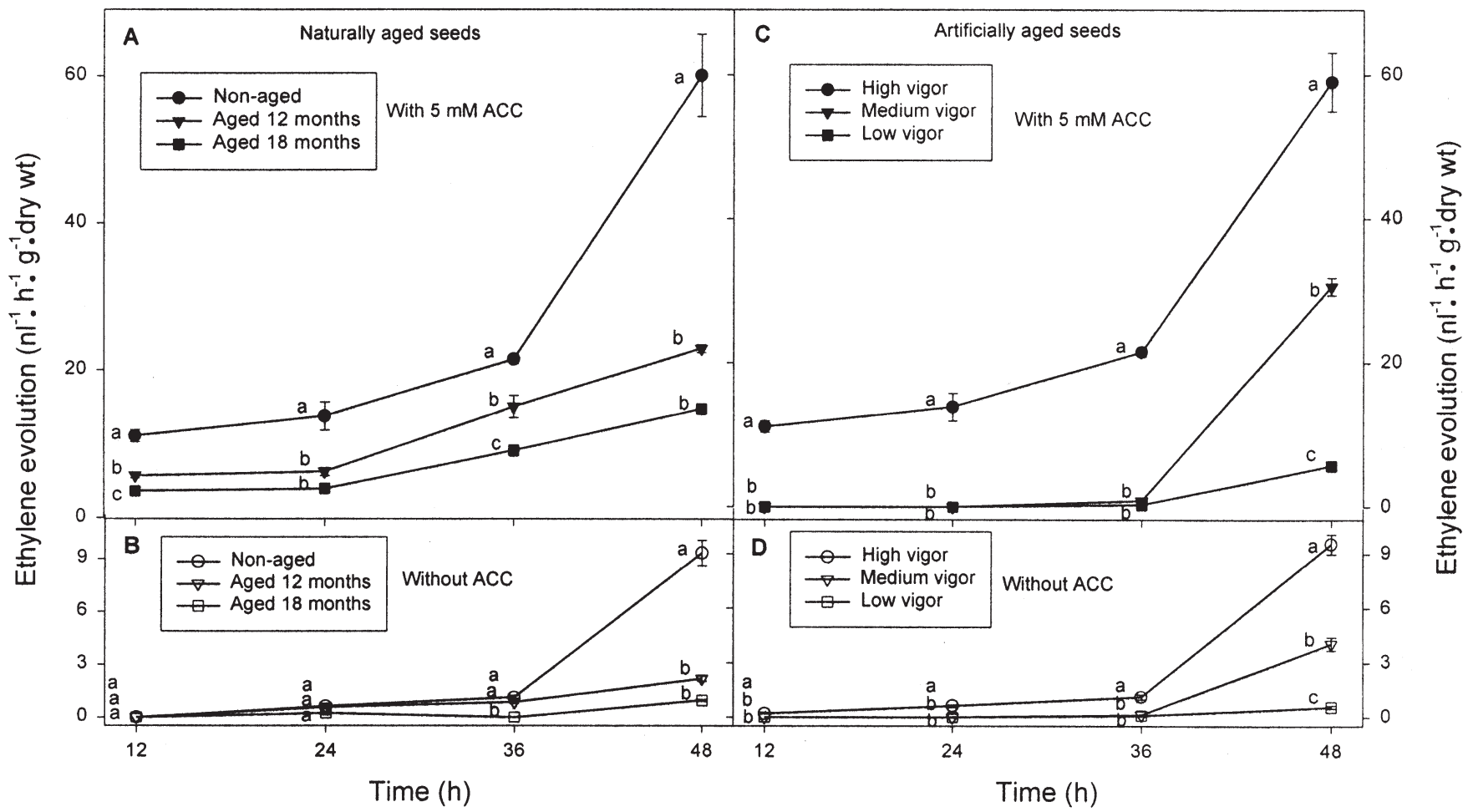

Fig. 2. Ethylene evolution from nonaged, naturally or artificially aged 'NewYorker' tomato seeds treated with or without 5 mm ACC. Values at each evaluation time were separated between aging treatment by Tukey's test $(P \leq 0.05)$. High-vigor and nonaged seeds commenced radicle protrusion at $48 \mathrm{~h}$ regardless of imbibition medium. Medium-vigor and all naturally aged seeds commenced radicle protrusion at $60 \mathrm{~h}$ and low-vigor seeds at $84 \mathrm{~h}$ regardless of imbibition medium. 


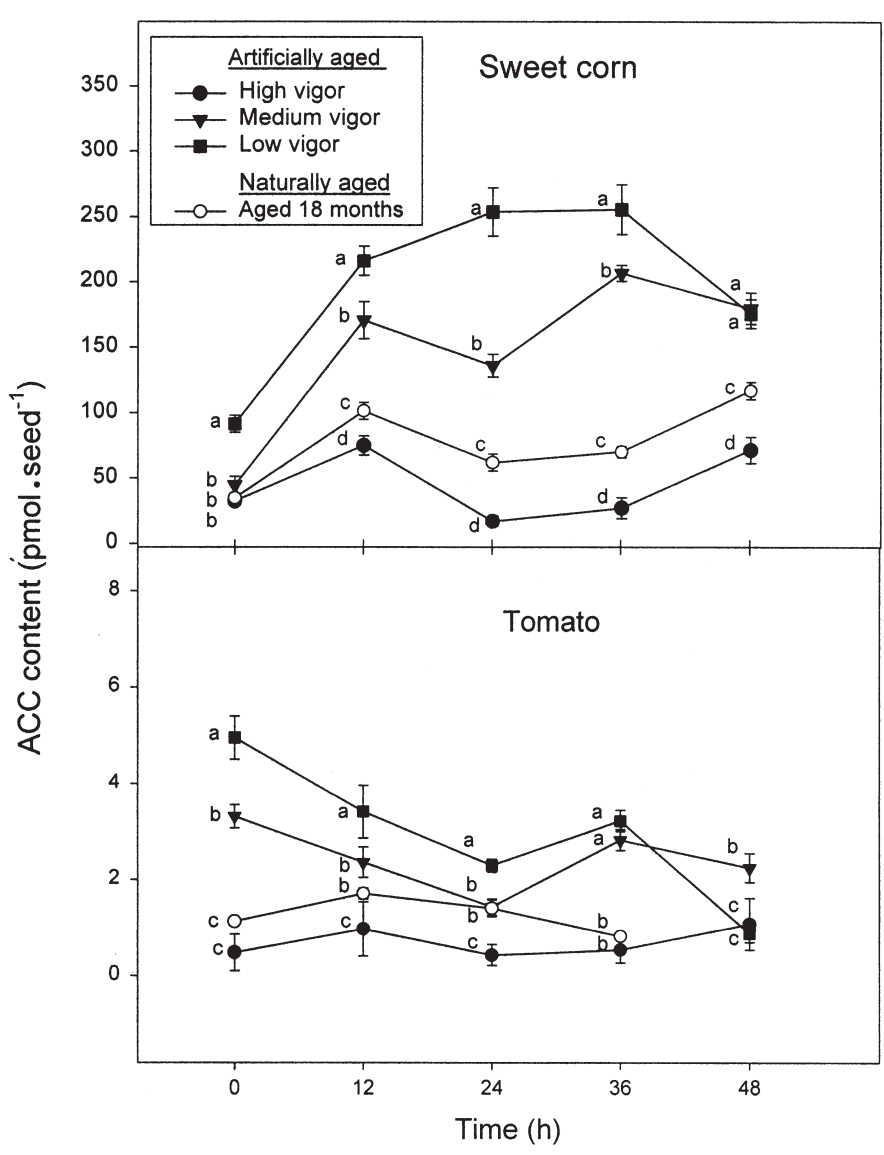

Fig. 3. ACC content from nonaged, naturally or artificially aged sweet corn and New Yorker tomato seeds following imbibition. Values at each evaluation time were separated between aging treatment by Tukey's test $(P \leq 0.05)$. Highvigor and medium-vigor sweet corn seeds commenced radicle protrusion at $48 \mathrm{~h}$. Low-vigor and 18-month naturally aged sweet corn seeds commenced radicle protrusion at $60 \mathrm{~h}$. Tomato seeds commenced radicle protrusion at 48 , 60,60 , and $84 \mathrm{~h}$ for high-vigor, medium-vigor, 18-month naturally aged, an low-vigor seeds, respectively.

this difference was more pronounced in the presence of exogenous ACC. Regardless of how seeds were aged, ethylene production after 36 or $48 \mathrm{~h}$, generally separated high-vigor from mediumvigor and low-vigor seeds. However, even though medium-vigor seeds consistently produced more ethylene than low-vigor seeds, it was not always possible to statistically separate the two vigor classes, especially without exogenous ACC (Figs. 1 and 2).

For both sweet corn and tomato, the pattern of ethylene evolution was similar between seeds aged naturally or artificially (Figs. 1 and 2). In contrast to ethylene production, endogenous ACC content was lowest in high-vigor, nonaged seeds for both sweet corn and tomato (Fig. 3). This was more pronounced in artificially aged compared to naturally aged seeds. In dry sweet corn seeds before imbibition, ACC content was only higher in low-vigor seeds. By $12 \mathrm{~h}$, there was a significant increase in ACC content for all vigor classes. Over the 48-h imbibition period examined, ACC content remained statistically lower for highvigor seeds compared to artificially and naturally aged seeds. In contrast, medium-vigor and low-vigor tomato seeds obtained by artificial aging had significantly more ACC before imbibition ( 0 $\mathrm{h})$ compared to nonaged and naturally aged seeds. Until $24 \mathrm{~h}$, ACC content in artificially aged seeds declined. ACC content in nonaged and naturally aged seeds remained unchanged for the 48-h period.
Artificially aged sweet corn seeds and 'Rutgers' and 'Ailsa Craig' tomato seeds required more time to complete $50 \%$ radicle protrusion than did nonaged seeds (Tables 4 and 5). Exogenous application of ACC to these seeds reduced the time to radicle protrusion, but did not completely reverse age-related effects on vigor. The same trend was observed in 'Rutgers' tomato seeds naturally aged for 18 months (data not shown). Exogenous application of ACC in the germination medium resulted in a 47- to 1200-fold increase of ACC content for sweet corn (Fig. 4) and a 170- to 6900-fold increase of ACC for tomato (Fig. 5) seeds imbibed in $5 \mathrm{~mm}$ ACC for 12 to $48 \mathrm{~h}$.

Northern blot analyses of sweet corn and tomato total RNA using a tomato $A C C O$ antisense RNA probe were only able to detect a transcript corresponding to $A C C O$ from nonaged, highvigor seeds (Fig. 6). For sweet corn, $A C C O$ transcript could only be detected from $48 \mathrm{~h}$-imbibed seeds in $5 \mathrm{~mm}$ ACC (Fig. 6A), while detection was possible in $48 \mathrm{~h}$-imbibed seeds in water and 5 mм ACC for tomato (Fig. 6B).

\section{Discussion}

Previous studies have concluded that the ability to produce ethylene during germination was a good indicator of seed vigor for several species (Gorecki, et al., 1991; Ketring et al., 1974; Khan, 1994; Takayanagi and Harrington, 1971). However, in these studies, seed lots identified as having low vigor also exhibited a significant loss in viability. Consequently, lower ethylene production found in these seed lots could have resulted from fewer viable seeds rather than seeds of low vigor. The current study used aging techniques that reduced seed vigor, as indicated by standard AOSA tests (McDonald, 1998), but retained high germination capacity (Tables 1-3). These seeds lots showed a strong, positive correlation between the ability to produce ethylene and seed vigor (Tables 1-3, Figs. 1 and 2). Results were consistent among seed lots reduced in vigor by either natural or artificial aging (Figs. 1 and 2). In addition, the current work reaffirms that ethylene evolution from ACC-treated seeds was a more sensitive indicator of seed vigor than seeds placed on water alone (Khan, 1994). Seeds germinated in the presence of exogenous ACC experienced an approximate 3- to 4-fold increase in ethylene production accentuating differences in ethylene evolving capacity from seeds of differing vigor. Similarly, Khan (1994), using seeds that varied in viability as well as vigor, showed an approximate 5-fold increase in ethylene production for ACC-treated high-vigor seeds compared to low-vigor seeds.

In contrast to ethylene production, endogenous ACC titers were not highest in seed lots with the highest vigor (Fig. 3). ACC content was highest in seeds treated by accelerated aging, suggesting that this stress induced ACC production during the 3 to $5 \mathrm{~d}$ of exposure to $78 \%$ relative humidity at $45^{\circ} \mathrm{C}$. Alternatively, accelerated aging

Table 4. Time (h) to complete $50 \%$ germination for 'Sugar King' sweet corn seeds with differing vigor levels treated with ACC.

\begin{tabular}{lccc}
\hline $\begin{array}{l}\text { ACC } \\
(\mathrm{mm})\end{array}$ & High & Medium & Low \\
\cline { 2 - 4 } 0 & $59.4 \pm 0.4 \mathrm{a}^{\mathrm{z}}$ & $62.3 \pm 1.7 \mathrm{a}$ & $73.0 \pm 1.8 \mathrm{a}$ \\
0.1 & $54.1 \pm 0.4 \mathrm{ab}$ & $58.1 \pm 1.0 \mathrm{~b}$ & $69.6 \pm 1.1 \mathrm{~b}$ \\
1.0 & $52.2 \pm 0.7 \mathrm{~b}$ & $58.8 \pm 0.3 \mathrm{~b}$ & $64.9 \pm 0.5 \mathrm{~b}$ \\
\hline
\end{tabular}

zMeans ( \pm standard error) are the time (h) required for $50 \%$ of the seeds to complete germination. Values within a column were separated by Tukey's test $(P \leq 0.05)$. At all ACC treatments means were significantly different among vigor levels. 
Table 5. Time (h) to complete 50\% germination for tomato seeds with differing vigor levels treated with ACC.

\begin{tabular}{lccr}
\hline & ACC & \multicolumn{2}{c}{ Vigor level } \\
\cline { 2 - 4 } Genotype & $(\mathrm{mm})$ & High & Medium \\
\hline 'Rutgers' & 0 & $78.6 \pm 1.3 \mathrm{a}^{\mathrm{z}}$ & $103.0 \pm 1.1 \mathrm{a}$ \\
& 0.1 & $76.6 \pm 0.5 \mathrm{a}$ & $100.9 \pm 1.5 \mathrm{a}$ \\
& 1.0 & $73.3 \pm 2.0 \mathrm{~b}$ & $98.7 \pm 1.2 \mathrm{~b}$ \\
& 0 & $73.8 \pm 1.0 \mathrm{a}$ & $98.7 \pm 2.0 \mathrm{a}$ \\
'Ailsa Craig' & 0.1 & $71.8 \pm 0.1 \mathrm{a}$ & $98.3 \pm 0.6 \mathrm{a}$ \\
& 1.0 & $67.3 \pm 1.4 \mathrm{~b}$ & $94.2 \pm 0.5 \mathrm{~b}$ \\
\hline
\end{tabular}

zMeans ( \pm standard error) are the time (h) required for $50 \%$ of the seeds to complete germination. Values within a column for each genotype were separated by Tukey's test $(P \leq 0.05)$. At all ACC treatments means were significantly different among vigor levels.

may reduce the ACC use capacity of seeds or liberate ACC from stored MACC. ACC was also detected in dry seeds from both sweet corn and tomato (Fig. 3) as previously documented for pea seeds (Gorecki etal., 1991; Petruzzelli etal., 2000). Following imbibition, ACC content increased in pea seeds, especially in the embryonic axis, but not in cotyledons (Petruzzelli et al., 2000). Additionally, the ACC titer of a nonaged pea seed lot (95\% germination) remained lower than that in an artificially aged seed lot (79\% germination) (Petruzzelli et al., 2000). In contrast, endogenous ACC was not detected in dry cocklebur seeds, but a significant increase in ACC content was documented after16 h of imbibition (Gorecki et al., 1991). After $48 \mathrm{~h}$ of imbibition, the synthesis of ACC in cocklebur increased three-fold in high-vigor ( $100 \%$ germination) compared to low-vigor seeds (57\% germination). However, the reduction in ACC synthesis in low-vigor seeds may be due to a loss in the ability to complete germination, (i.e., poor viability) and not to lower seed vigor.

Imbibing seeds on ACC provided some insight into the ability of high- and low-vigor seeds to convert ACC to ethylene. High- and low-vigor seeds from both sweet corn and tomato demonstrated an ability to convert ACC to ethylene after12 $\mathrm{h}$ in seed lots that

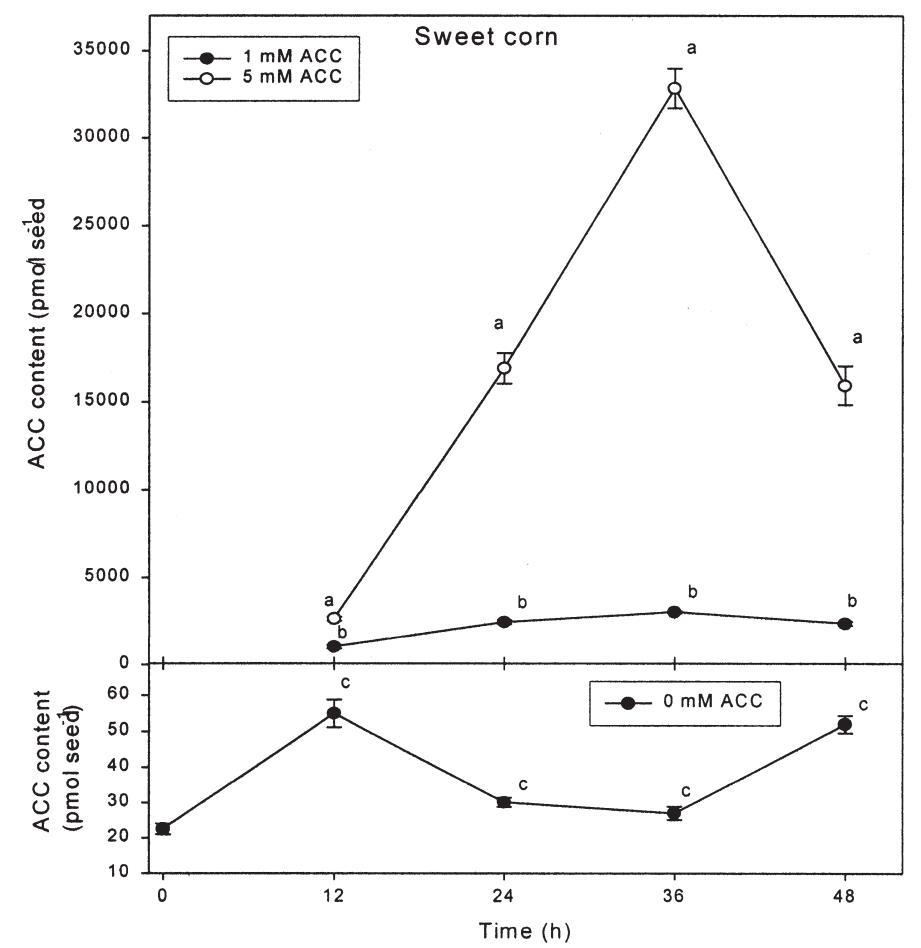

Fig. 4. ACC content in sweet corn seeds treated with saturating levels of exogenous ACC. Bars indicate standard error. Seeds commenced radicle protrusion at $36 \mathrm{~h}$ when imbibed on ACC, regardless of the concentration and at $48 \mathrm{~h}$ on water. were naturally aged (Figs. 1 and 2). However, the quantity of ethylene production was significantly greater in nonaged seeds. Khan (1994) also showed that artificial aging for 3 or 5 d decreased ethylene production 2.3 - and 4.7-fold, respectively, when tomato seeds were imbibed on $1 \mathrm{~mm}$ ACC for $30 \mathrm{~h}$.

In this study, medium-vigor and low-vigor tomato seeds from artificial aging were unable to convert ACC to ethylene until 48 $\mathrm{h}$ and in all cases aged seeds showed a reduced capacity to convert ACC to ethylene (Figs. 1 and 2). Furthermore, exogenous application of ACC to aged seeds could not completely reverse the age-related increase in the time to complete $50 \%$ germination. This could be the result of either reduced ACCO function from existing enzyme or reduced capacity for synthesis of $A C C O$ transcript, protein, or both. Using a tomato antisense probe, it was possible to detect $A C C O$ transcripts from total RNA only after $48 \mathrm{~h}$ in nonaged seed from both tomato and sweet corn (Fig. 6). After $48 \mathrm{~h}$, no ACCO transcripts were found in low-vigor seeds. This suggests that seeds differing in vigor quality had altered $A C C O$ mRNA synthetic capacity. Using more sensitive poly(A)+ mRNA extracts from germinating pea seeds, Petruzzelli et al. (2000) detected $A C C O$ transcripts after $8 \mathrm{~h}$ followed by ethylene

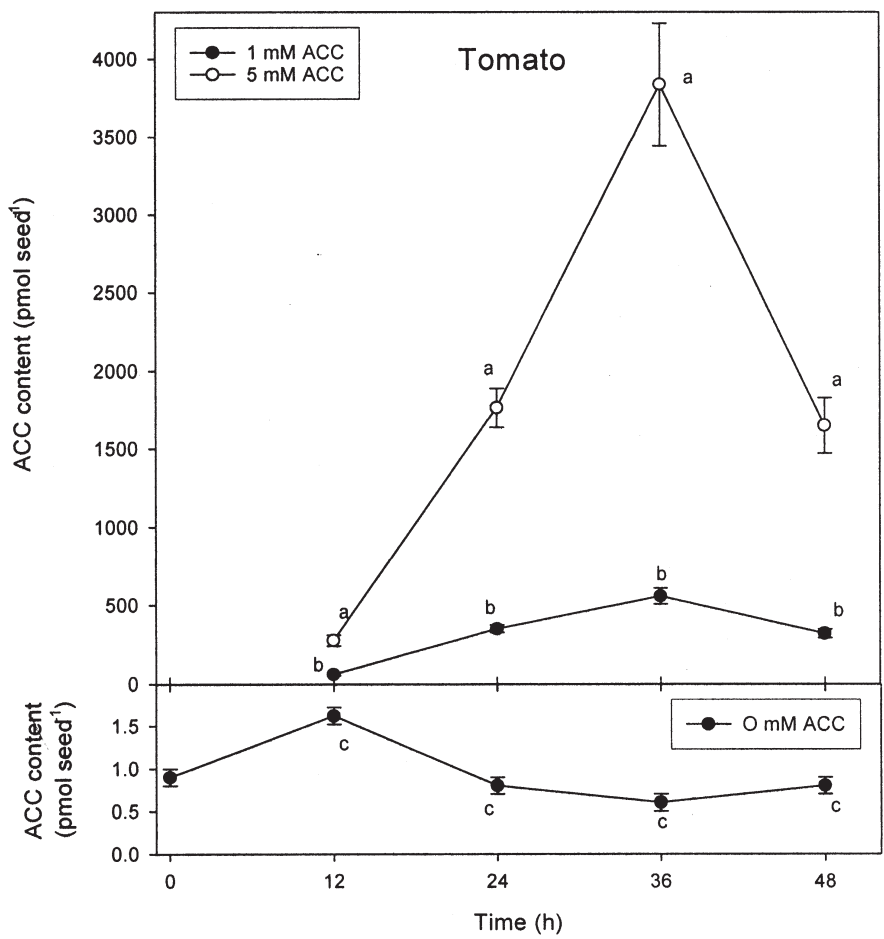

Fig. 5. ACC content in tomato seeds treated with saturating levels of exogenous ACC. Bars indicate standard error. Seeds commenced radicle protrusion at 48 $\mathrm{h}$ regardless of the imbibition medium. 
Corn

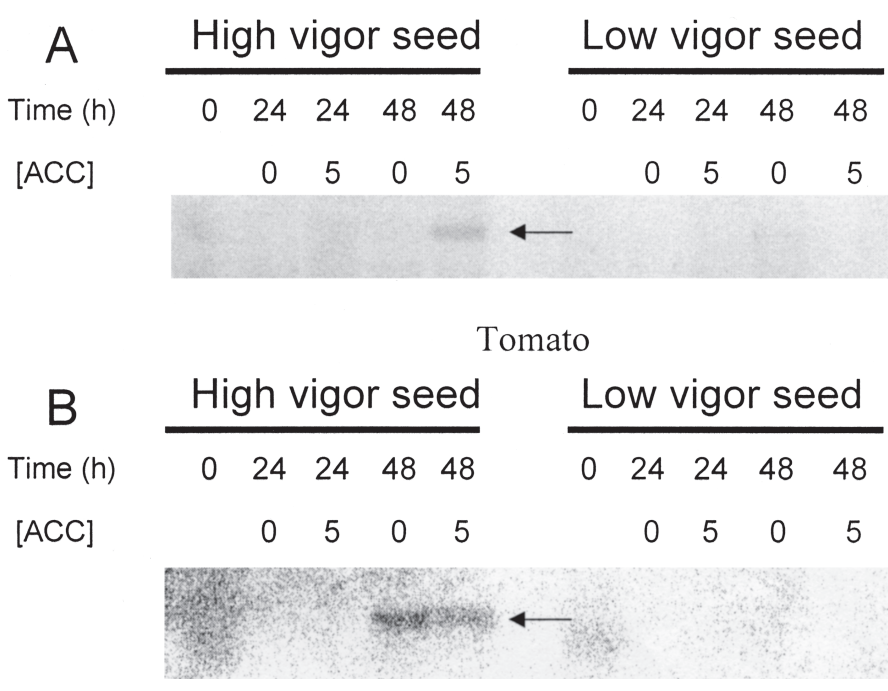

Fig. 6. Autoradiogram of sweet corn (A) and tomato (B) northern blots hybridized with $\mathrm{LeACCO} 4$ antisense riboprobe (generated from the $\mathrm{LeACCO} 4$ partial-length cDNA). Time $(\mathrm{h})=$ hours of imbibition.

production after 15 to $20 \mathrm{~h}$. Since the current study used total RNA extracts, it is reasonable to assume that $A C C O$ mRNA would be similarly produced earlier as observed in pea, because ethylene production was also detected by $12 \mathrm{~h}$ in nonaged sweet corn and tomato seeds (Figs. 1 and 2).

The reduced ability to synthesize ACCO in aged seeds could be a nonspecific reduction in general protein synthesis in aged seeds. Before completion of germination of sunflower seeds, a high-quality seed lot (98\% germination) showed greater total RNA content, total RNA synthetic capacity, and protein concentration (Reuzau and Cavalié, 1997) than a seed lot of lower quality (86\% germination). This may be due to a generally greater ability of high-vigor, relative to low-vigor, seeds to synthesize poly (A)+ mRNA (Grilli et al., 1995). Guy and Black (1998) also reported that in artificially aged wheat seeds there was a delay in the production of specific mRNA and protein accumulation required for radicle protrusion. During germination of chick-pea seeds, $A C C O$ mRNA was clearly present after $6 \mathrm{~h}$ and increased to a maximum after 24 h (Gómez-Jimémez et al., 1998). Therefore, Gómez-Jimémez et al. (1998) suggested that ACCO in chick-pea was regulated at the level of transcription during seed germination. This also appears to be the case in tomato and sweet corn and the reduced ability to produce ethylene in aged seeds may be accounted for by reduced $A C C O$ transcription.

The current study provides additional support for ethylene as a biochemical indicator of seed vigor by critically evaluating ethylene production from seed lots with reduced vigor but high germination capacity. Many of the studies that have previously determined a link between ethylene and seed quality have used some form of artificial aging. The current study demonstrates that seeds exposed to artificial aging using SSAA responded similarly to seeds that were naturally aged with regards to ethylene evolution. However, this study used only single seed lots of sweet corn and tomato, which were subsequently aged to provide seeds with reduced vigor. Additional studies are required using numerous seed lots and cultivars with different vigor levels to determine quantitative levels of ethylene production that would be indicative of the vigor for each seed lot.

\section{Literature Cited}

Association of Official Seed Analysts. 1983. Seed vigor testing handbook, No. 32. Assn. Offic. Seed Analysts.

Association of Official Seed Analysts. 1993. Rules for testing seeds. J. Seed Technol. 16:1-113.

AusubelF.M., R. Brent, R.E. Kinston, D.D. Moore, J.A. Smith, J.G. Sedman, and K. Struhl. 1987. Current protocols in molecular biology. Wiley-Interscience, N.Y.

Byrum, J.R. and L.O. Copeland. 1995. Variability in vigour testing of maize (Zea mays L.) seed. Seed Sci. Technol. 23:543-549.

Copeland L.O. and M.B. McDonald. 1995. Principle of seed science and technology. 3rd ed. Chapman \& Hall, N.Y.

Finlayson, S.A., I.J. Lee, J.E. Mullet, and P.W. Morgan. 1999. The mechanism of rhythmic ethylene production in sorghum. The role of phytochrome B and simulated shading. Plant Physiol. 119:1083-1089.

Gómez-Jiménez, M.C., A.J. Matilla, and D. Garrido. 1998. Isolation and characterization of cDNA encoding an ACC-oxidase from Cicer arietinum and its expression during embryogenesis and seed germination. Austral. J. Plant Physiol. 25:765-773.

Gorecki, R.J., H. Ashino, S. Satoh, and Y. Esashi. 1991. Ethylene production in pea and cocklebur seeds of differing vigor. J. Expt. Bot. 42:407-414.

Grilli, I., E. Bacci, T. Lombardi, C. Spano, and C. Floris. 1995. Natural ageing: Poly(A) polymerase in germinating embryos of Triticum durum. Ann. Bot. 76 15-21.

Guy, P.A. and M. Black. 1998. Germination-related proteins in wheat revealed by differences in seed vigour. Seed Sci. Res. 8:99-111.

International Seed Testing Association. 1993. International rules for seed testing Seed Sci. Technol. 21 suppl.

Ketring,D.L.,P.W. Morgan, and R.D. Powell. 1974. Relations of ethylene production to germinability and growth of two oil seeds, cotton and peanuts, p. 891-899. In Y. Sumiki (ed.). Plant growth substances. Hirokawa Publ. Co., Tokyo, Japan.

Khan, A.A. 1994. ACC-derived ethylene production, a sensitive test for seed vigor. J. Amer. Soc. Hort. Sci. 119:1083-1090.

Lizada, M.C.C. and S.F. Yang. 1979. A simple and sensitive assay for 1-aminocyclopropane-1- carboxylic acid. Anal. Biochem. 100:140-145.

Matilla, A.J. 2000. Ethylene in seed formation and germination. Seed Sci. Res. 10:111-126.

McDonald, Jr., M.B. 1995. Seed lot potential: viability, vigour and field performance. Seed Sci. Technol. 22:421-425.

McDonald, Jr., M.B. 1998. Seed quality assessment. Seed Sci. Res. 8:265-275.

McKeon, T.A., N.E. Hoffman, and S.F. Yang. 1982. The effects of plant-hormone pretreatments on ethylene production and synthesis of 1-aminocyclopropane-1carboxylic acid in water-stressed wheat leaves Triticum aestivum. Planta 155: 437-443.

Nakatsuka, A., S. Murachi, H. Okunishi, S. Shiomi, R. Nakano, Y. Kubo, and A. Inaba. 1998. Differential expression and internal feedback regulation of 1 aminocyclopropane-1-carboxylate synthase, 1-aminocyclopropane-1-carboylate oxidase, and ethylene receptor genes in tomato fruit during development and ripening. Plant Physiol. 118:1295-1305.

Petruzzelli, L., I. Coraggio, and G. Leubner-Metzger. 2000. Ethylene promotes ethylene biosynthesis during pea seed germination by positive feedback regulation of 1-aminocyclopropane-1-carboxylic acid oxidase. Planta 211:144-149.

Reuzeau C. and G. Cavalié. 1997. Changes in RNA and protein metabolism associated with alterations in the germination efficiency of sunflower seeds. Ann. Bot. 80:131-137.

Takayanagi, K. and J.F. Harrington. 1971. Enhancement of germination rate of aged seeds by ethylene. Plant Physiol. 47:521-524.

TeKrony D.M. and D.B. Egli. 1991. Relationship of seed vigor to crop yield. A review. Crop Sci. 31:816-822.

TeKrony, D.M. and J.M. Woltz. 1997. Standardization of the cold test for corn seed. Proc. Corn Sorghum Res. Conf. 52:206-227.

van de Venter, H.A., G. Barla- Szabo, and S.G. Ybema. 1993. A study of single and multiple stress seed vigour tests for undeteriorated seed lots of wheat. Seed Sci. Technol. 21:117-125.

Wan, C.Y. and T.A. Wilkins. 1994. A modified hot borate method significantly enhances the yield of high-quality RNA from cotton (Gossypium hirsutum L.). Anal. Biochem. 223:7-12.

Woodstock, L.W. 1973. Physiological and biochemical tests for seed vigor. Seed Sci. Technol. 1:127-157. 